\title{
LEADERSHIP AS CULTURAL PRACTICE
}

\section{OTACÍLIO TORRES VILAS-BOAS}

Tribunal Regional do Trabalho da $2^{\text {a }}$ Região, Salvador, Bahia, Brazil.

\section{EDUARDO PAES BARRETO DAVEL}

Universidade Federal da Bahia, Salvador, Bahia, Brazil.

\section{MARCELO DE SOUZA BISPO}

Universidade Federal da Paraíba, João Pessoa, Paraíba, Brazil.

To cite this paper: Vilas-Boas, O. T., Davel, E. P. B., \& Bispo, M. de S. (2018). Leadership as cultural practice. Revista de Administração Mackenzie, 19(1). doi 10.1590/1678-6971/eRAMG180076

Submission: Jul. 07, 2017. Acceptance: Sep. 14, 2017.

\section{(cc) BY}

\footnotetext{
This paper may be copied, distributed, displayed, transmitted or adapted if provided, in a clear and explicit way, the name of the journal, the edition, the year and the pages on which the paper was originally published, but not suggesting that RAM endorses paper reuse. This licensing term should be made explicit in cases of reuse or distribution to third parties. It is not allowed the use for commercial purposes.

Este artigo pode ser copiado, distribuído, exibido, transmitido ou adaptado desde que citados, de forma clara e explícita, o nome da revista, a edição, o ano e as páginas nas quais o artigo foi publicado originalmente, mas sem sugerir que a RAM endosse a reutilização do artigo. Esse termo de licenciamento deve ser explicitado para os casos de reutilização ou distribuição para terceiros. Não é permitido o uso para fins comerciais.
} 


\section{ABSTRACT}

Objective: This article proposes the study of leadership as cultural practice, adding the cultural dimension to research on leadership as practice.

Originality/Value: While the advances of practice-based studies are considerable in organizational learning and strategy, research on leadership as practice is scarce. Within the field of leadership as practice, in which no research has integrated the cultural dimension, this article formulates and discusses leadership as cultural practice, because it understands that culture is a fundamental element in not only orienting how organizational practices are constructed, but also in how leaders make and base their decisions, as well as act and interact.

Design/methodology/approach: The first step of this research is the review of the studies on leadership as practice. The second is to bring these studies closer to those dealing with cultural leadership and culture as practice. The third step is to discuss the implications of the proposal of leadership as cultural practice.

Findings: The results of the research allow to enlarge and improve the study of leadership, considering it not only as practice, but also as cultural practice. Implications for future research are discussed.

\section{KEYWORDS}

Leadership. Practice. Culture. Cultural practice. Practice-based studies. 


\section{INTRODUCTION}

In terms of epistemology, the sense of practice means a singular way of thinking about social research and several ways of organizations (Nicolini, Gherardi, \& Yanow, 2003; Santos \& Silveira, 2015; Schatzki, 2001, 2006). While the advances of practice-based studies are considerable in organizational learning and strategy, research on leadership as practice is scarce and does not take part in a cultural extent, which is intrinsic to the leadership phenomenon. Therefore, it is necessary a more precise understanding of the current practices, in other words, to go further beyond the icon of "hero" leader and leadership should be regarded as a group and cultural phenomenon, taking the meaning of leadership out of an isolated and individual perspective into a collective one that beholds the organizational dynamics in a more practical manner.

The practice theories, each in their own way, have in common the fact that all of them try to overcome dichotomies such as subject/object, mind/ body and agency/agents, changing the emphasis to the practices. Besides, outstanding some assumptions (Bispo, 2015; Nicolini, 2013):

a) The practice as analysis unity to understand the organizational phenomena, because it is through the practices that it is possible to access and understand the action, the agencies and the agents. The theories of the practice provide a possibility to reinterpret the organizational phenomena;

b) The practices are the creation of a meaning, identity formation and the planning of the production of activities. The theories of the practice give up a performing view in such a way to offer a new one beyond the social world which goes much further besides describing what people do, something rather common according to rationalist and positive views of the social sciences;

c) The cognition and creation of meaning come from the practices of an organization. A vision based on the practice is an option to the cognitive perspective, which tries to explain the organizational behavior starting from the individual minds;

d) The creation of meaning is not limited by an intangible mental process, a form of symbolic exchange or an abstract process based on a sheer communicative process. The creation of meaning is concrete and identified by means of artifacts, speeches, bodies, habits and concerns;

e) The relationships are made of groups or networks of practices. 
According to the studies on organizational learning, the practice approach has brought new elements to discussion, such as the role of emotions in the learning process, the political, power and domination influence in the content of learning, and also the interdependence between the processes of learning and organizing (Bispo, 2013a; Flach \& Antonello, 2011; Gherardi, Nicolini, \& Odella, 1998). As stated in the studies about strategy, the practice approach could recognize, for instance, that the strategy work is widely distributed in the organizations, not only taking into account the participation of the employees at higher hierarchical levels, but also the ones at medium and lower levels, (Jarzabkowski, 2005; Samra-Fredericks, 2003; Silva \& Gonçalves, 2016; Vaara \& Whittington, 2012; Whittington, 2003).

In the area of leadership, research is dominated by a theoretical approach with a super focus on the figure of the leader, not considering the context in which the leadership occurs with several human and nonhuman actors. Traditionally, research is presented with focus on personality traits (Stogdill, 1948), interaction including leaders and followers (Stogdill \& Coons, 1957) and style adaptation to situations (Fiedler, 1967; Parry \& Bryman, 2006). Nowadays, we have a debate about perspectives of leadership as a plural and collective activity, diverting focus from activities only concentrated on the leader (Denis, Langley, \& Sergi, 2012; Parry \& Bryman, 2006). According to these views, the leadership activities involve more than one person and some organizations are formal arrangements to share leadership responsibilities and tasks, which is considered preferably as collaborative (Collinson \& Collinson, 2009). This way, leadership is seen as a sharing phenomenon among the collective members, with interdependency, related to social interactions providing learning (Denis, Langley, \& Sergi, 2012; Fletcher \& Kaufer, 2003). From an epistemological point of view, leadership is considered, traditionally, something positive, with studies directed to discover and document laws to the human behavior and to control and forecast events. This way, reality is considered to be formed by stable patterns, which can be discovered through empirical objectivism (Neuman, 2003).

Recently, some studies regard leadership as practice (Carrol, Levy, \& Richmond, 2008; Crevani, Lindigren, \& Packendorff, 2010). In such perspective, leadership is considered to be a social construction that concerns the processes carried out in a specific field. Surely, leadership is not only formed by random and coordinated conversations, but also by other communicative acts that pass on a collective conscious from a community (Raelin, 2011). For instance, a person in a collective situation that tries to establish a vision and direction to the group can be seen as a leader in this 
particular setting. However, this same person, involved in this same behavior but in a different situation, with another collective, can be seen as someone trying, illegitimately, constrain the collective to follow a certain direction or in disagreement with their role in the collective. The focus is not on the people as leaders or followers, but on the actions in which they are involved and on the social processes in which people give meaning to these actions (Derue, 2011).

Within the field of leadership as practice, in which no research has integrated the cultural dimension, this article formulates and discusses leadership as cultural practice, because it understands that culture is a fundamental element in not only orienting how organizational practices are constructed, but also how leaders make and base their decisions, as well as act and interact. In order to achieve this goal, the article is made of three steps. The first one is the review of the studies on leadership as practice (first part). The second one is to bring these studies closer to those dealing with cultural leadership and culture as practice (second part). The third step is to discuss the implications of the proposal of leadership as cultural practice (third part).

From a methodological point of view, it is a research with a theoretical vocation, which rereads, contrasts and integrates the academic production of three areas: leadership as practice, cultural leadership and culture as practice. Certainly, the field of research on leadership is old and wide. We investigated the production of this field in this article, but we have chosen and considered only the articles and books that tackled one or several of these areas. We also highlight that we do not consider leadership as practice as a synonym of practice of leadership. The latter is a generic term, while the former talks about an epistemological positioning.

\subsection{From Practice-Based Studies to Leadership as Practice}

With the advances of organizational studies, especially in terms of understanding the subjectivity and intersubjectivity, as well as tacit and aesthetic aspects, there is a need to search new ontological, epistemological, theoretical and methodological contributions so that it is possible to expand and deepen the understanding about the phenomenon connected to the organizations. In this context, the practice-based studies appear (Bispo, 2013b; Gherardi, 2006). The epistemology of practice allows researchers to work with the phenomena inside a particular situation, considering that temporality and historicity are really important to have a better understanding 
of the social worlds (Reckwitz, 2002). There is a common aspect among the approaches based on practice in the organizational studies, which is the wish to bring a new view at the organizational phenomena by bringing it closer in relation to what is really concrete at work in the organizations (Gherardi, 2006). In this sense, we should not just explore what people do individually in the organizations, but try to answer why and how the collective actions are performed, which institutional powers of these actions (practices) reveal and how they are modified and their implicit rules are questioned and reflected inside the context of their practitioners (Geiger, 2009).

The practice-based studies assume that the social is not just related to human beings, but also symbolic and cultural artifacts. The notion of practice is rich, as you articulate the notion of space-time of what the actors do, it means, specific practices that involve uncertainties, conflicts and inconsistencies, which are intrinsic characteristics of these practices, enabling considerable insights and contributing to the understanding of the dynamics of an organization, as well as a course of changes inside a social system (Antonello \& Godoy, 2009). Since knowledge is connected to what is done/practice, Cook and Brown (1999) point out that the epistemology of practice is able to convey the coordinated activities of an individual and groups at the moment of their tasks, considering the particular context of the individual and the organization.

The daily life of organizations is formed by negotiation among people and groups, which involves the meaning of words, actions, situations and material artifacts. These elements, which are constantly formed by the activities performed by the actors, take part in and contribute to a culturally structured social world (Gherardi, 2006). Therefore, the social practices have a relevant role in the social organization and in their perpetuation and changes (Bispo, 2013b).

There is no consensus about the definition of practice. However, what there is common among the presented definitions is that the practice is a result of a set of articulated activities and demand an interaction between humans and material elements in order to be considered practice (Gherardi, 2006; Hui, Schatzki, \& Shove, 2017; Reckwitz, 2002, Schatzki, 2001). In the area of leadership, there is a need of a more precise understanding of how practices of leadership are performed. Research about leadership is always emphasizing the qualities that leaders should have (trust, optimism, charisma, etc.), their behavior (inspire, set the example, etc.), the intelligences to be developed (cognitive, emotional, spiritual, etc.), required guidance (tasks or people) and the nature of their work (interpersonal, adaptive, strategic, etc.) Thus, there are several typologies and descriptions that 
highlight specific styles or effects (transformational, transactional, server, authentic leadership) and a great deal of abilities and tools that outline the expectations of what needs to be dominated. Nevertheless, the focus is on "what" and on "why", and not on "how" (Chia, 2004).

However, recent research has started to discuss leadership as practice, from considerations that reveal that practice approach can provide a better understanding about the phenomenon of leadership, bringing the focus to "how". Leadership occurs as a relational process, arising from interactions and communications among actors inside a context. Surely, leadership is not only a result of social processes, but also a contextual element that influences interactions. Thus, daily-shared conversations play an important role in the production of leadership (Uhl-Bien, 2006; Vine, Holmes, Marra, Pfeifer, \& Jackson, 2008; Wood 2005).

The everyday processes through which members of the organizations build notions of direction, guidance and space of action, are, in a sense, places, but also produce organizational and social rules. So, instead of traditional concepts, the understanding of leadership can be developed as a continuous process in which there are performance rules to some specific cases, people act together, and perceptions of emerging structures and ambiguities interact constantly. Actually, leadership is a widespread activity that might be associated with formally nominated leaders or not. Thus, leadership can be analyzed by practices connected to people who are interacting. As a result, leadership is the level of analysis itself. The empiric focus is on the practices of leadership, and not only on the leaders (Crevani, Lindgren, \& Packendorff, 2010).

The approach of practice offers a different view from the one based on the leaders' individual competences, in such a way that it is possible to have a broadened understanding about the phenomenon of leadership. It is a way that allows understanding of the internal dynamics of the leadership processes as a collective practice, considering all the people involved in the leadership action. While the approach that is centralized on the leaders' competence takes root in the individualism, cognitivism and measurement, disregarding the context where leadership occurs, the practice approach is clearly constructivist, relational, collective, and is based on the speech, rhetoric and in the narrative. Therefore, understanding leadership as practice is to take it as something socially placed and defined (Carroll, Levy, \& Richmond, 2008).

This approach is inspired in the same reviews of Bispo and Mello (2012) where they presented the "myopia of organizational learning", when the 
process of organizational learning is treated in a similar way as an individual learning. It is necessary to understand the organizational learning as a practice, and not just as a result of individual learning. Consequently, leadership is considered an individual as well as a collective phenomenon, both ways taking into account a practice that is guided by the contextual aspects where it is performed.

The focus on the leaders' individual competences, the traditional perspective of leadership research, represents a limitation in relation to the possibilities when we think about and develop leadership as a complex and collective phenomenon. On the other hand, the notion of practice is in line with the search of understanding of the modus operandi of the leadership, allowing studies to be directed towards issues such as where the work of leadership is done, who and which nonhuman elements are involved in such work, and how it is organized, communicated, and assimilated.

Through the practice approach, it is possible to look for stronger versions for the explanation of leadership, originated from a closer interaction with the practitioners and a better understanding about the importance of the use of language to perform actions and the construction of an organizational or social order (Carroll, Levy, \& Richmond, 2008). Since the view of leadership as practice embraces what is internalized, spontaneous, and improvised, aspects such as what is not said, not articulated, and the unconscious gain importance to understand leadership as a collective phenomenon (Chia \& MacKay, 2007).

Leadership is related to mechanisms of social interaction that enable the development of solutions of daily problems located within the society in general, and the studies associated to the practices, considering the social, historic and structural context, allowing the understanding of tacit and hidden knowledge in the collective production of leadership. The perspective of practice allows the researchers to research empirically how the contextual elements shape knowledge and how the collective competence (knowledge in action) is constructed around a contingent logic of practice.

The findings and perceptions through the practice perspective can identify, inside the relationships of leadership, organizational levers to make changes in certain activities, as well as support and reinforce the appropriate practices. Such levers are grounded in the dynamics of daily interactions and highlight the relevance of the actions of all participants in the production of results (Feldman \& Orlikowski, 2011).

To sum up, studying leadership as practice means to analyze, through the experience and the interaction with practitioners (leaders and followers) and the nonhuman elements (artifacts, aims, objectives, strategies, etc.), 
how it is developed, that is, seeking to reveal which set of existing activities are, how they are, what they represent and how they are connected, it means, the practices - considering that leadership is collective, relational and contextualized.

\subsection{From Leadership as Practice to Leadership as Cultural Practice}

In the field of organizational studies, the concept of culture is seen in two different levels: the organizational culture one and the social culture one. The concept of organizational culture comes from a social-anthropologic approach focused on the notion of culture as a set of shared principles that rules groups that make part of organizations. According to dominant theories, organizational cultures differ and characterize the modus operandi of these organizations as formally structured collectivities (Schein, 1992). The organizational studies also regard culture from the notion of nationality, that is, from the national or social culture. According to dominant research, social culture refers to a set of beliefs, principles and values, which are shared with members of the same society (House, Hanges, Javidan, Dorfman, \& Gupta, 2004).

There is no leadership without a culture. Leadership is a cultural expression which involves issues and conflicts connected to the leaders and followers inside a variety of international, national, regional and organizational contexts. Based on the research around cultural leadership, we can say that leadership represents a social action, which is expressed in its symbolic activity and the creation of meaning. Leadership is conceived as a symbolic action that represents influence on the objectives and strategies, on the commitment and consent in relation to the necessary behaviors to achieve the objectives, on the lifetime and identification of the group and on the culture of an organization.

Leadership is seen as a central activity of organizational actors that develop, shape and negotiate the contents of interpretive patterns which define the daily working situations (Smircich \& Morgan, 1982). Leadership is also understood as the ability to create a field of meaning integrated to the common purpose of enabling people to find out their own roles and focus on their personal intention, ability and vocation. In this field, the patterns of possibilities, usually referred as views, highlight opportunities and guide actions (Varney, 2009). Thus, leaders are regarded as influential factors/ administrators of direction, guiding the followers to what is important, and in this way defining the organizational reality (Ferraz \& Fischer, 2001). The 
leader's effectiveness lies in his ability to make an activity meaningful to his followers, giving them a sense of understanding and relevance to what they are doing (Smith \& Peterson, 1989).

Based on the studies around cultural practice, it can be said that the practices - or how things are done - are connected to the cultural processes, because they are the ones that guide the action and provide basis to understand world (Giorgi, Lockwood, \& Glynn, 2015). Broadly speaking, the practices refer to the daily activities which are generally unconscious and automatic (Swidler, 2001). Culture not only represents an organizational feature, but also something that people produce (Whittington, 2006). Practices and culture are theoretically related but empirically distinct, this way allowing the study about how actions and meanings are configured and questioned over the time. Although many recent projects about culture have aimed at conscious cognitive processes or at strategic decisions in the use of culture, a focus on the practice can help to explain better how and why culture influences several organizational processes, at times without an intentional planning or even a conscious acknowledge by the side of the involved actors (Giorgi, Lockwood, \& Glynn, 2015).

The studies of organizations though practice have appointed some problems such as how processes and the logic of actions are established at different spaces of acts in everyday work (Sandberg \& Dall'Alba, 2009). The practices are analyzed based on the activities in progress, time and procedures (Gherardi, 2010). Just as leadership, the practice approach is, naturally, cultural as well (Reckwitz, 2002), because it considers the explanation and the understanding of actions - where cultural identities are presented through the reconstruction of symbolic structures of knowledge that enables and limit the agents in relation to the interpretation of world and behavior. So, the social order is not a result of accomplished normative mutual expected tasks, but inserted in collective structures, with shared knowledge that allows a social way to give meaning to the world, even pointing out which standards are considered legitimate. Through the practice approach it is possible to explore how activities of understanding and knowledge are included in a set of actions. Thus, taking into account the speeches, an analysis is made in the interconnections among the routines of understanding and knowledge, the behavioral bodily routines, and the use of objects (Reckwitz, 2002).

The practices that structure the interaction and guide the interpretation anchor the behavior and the creation of meaning (Swindler, 2001). Some studies have revealed that practices can evolve the way and alter the organizational system as a whole, including the organizational culture 
(Canato, Ravasi, \& Phillips, 2013; Feldman, 2000; Feldman \& Orlikowski, 2011; Orikowski, 1996). Apparently, ordinary activities, such as meetings, trainings and everyday interactions, can motivate cultural changes - such activities might create space where familiar and unknown elements may be recombined to modify the dominant organizational culture (Howard-Grenville, Golden-Biddle, Irwin, \& Mao, 2011).

Although most research on culture is associated with cognition (DiMaggio, 1997), culture also guides the everyday practices and gives several particular meanings to them. So, though exogenous and endogenous practices might change the organizational culture, the practices themselves are also incorporated and influenced by wider cultural systems (Giorgi, Lockwood, \& Glynn, 2015). According to Bourdieu (1977, 1990), the cultural environment where a person is born and socializes, according to his or her social class, creates a structure related to feeling, thinking and acting habitus -, which is kept almost unconsciously over the years and incorporated in his behavior and habits. The practices are considered to be highly influenced by the cultural environment where the actors are integrated - the practices are seen as manifestations of values and assumptions shared among the members of an organization (Van Maanen, 1979)

Recent research connecting culture and practices starts to emphasize a more interactive relation. A study related to a software (Orlikowski, 2000), for instance, observed how and why the final user uses the software in a rather different way from that which the designers had intended, not considering the central collaborative resources. In such case, the practices were influenced by a culture of skepticism around the technology; such beliefs, on the other hand, were reinforced when the technology failed, showing that culture and practices supported each other.

Leadership is formed by the actors' practices inside the context where they act, and these practices shape and are shaped by the actors' beliefs. Beliefs and practices of a collectivity produce, along the years, an intelligible nexus to the collectivity (Schatzki, 2001), with sense and meaning. This way, leadership is connected to a culture that comprises collective and individual beliefs, and that works as the basis to analyze leadership as a manifestation of a whole collectivity. Leadership is not inside the individuals' (leaders') minds, but in the interaction of beliefs and actions of the collective environment (Drath, 2001; Drath \& Palus, 1994; Drath et al, 2008; Hosking, 2006). Therefore, we can state that leading is culture practicing.

Different collectivities are likely to present several cultural references. The practices of leadership in a specific context are associated with the 
beliefs and behaviors of everyone that thinks and interacts in such context. So, leadership can be understood and studied as a cultural practice. This way, the understanding of leadership must be seen inside a context considering the observed practices, having leadership itself as the level of analysis, and considering that such practices are connected to culture, regarding leadership associated with a cultural set that encompasses individual and collective beliefs. Thus, the view of leadership as cultural practice includes the explanations of actions and interactions, rebuilding the symbolic structures of knowledge, and allowing leaders and followers to interpret the world according to certain forms and to behave in a way in agreement with the existing culture.

Knowledge involves more than knowing in the practices of leadership. It includes forms of understanding, experiences and manners of wishing and feeling that are interconnected, representing a way to understand the world, including leaders, followers and objects (including the abstract ones). This manner of understanding is formed by cultural references. So, the shared and collective knowledge is not a sheer result of the contents of individual minds - it has a social character, involving the continuous and repetitive interaction among people and objects (Reckwitz, 2002).

Therefore, studying leadership as cultural practice means analyzing, through experience and interaction among the practitioners (leaders and followers) and nonhuman elements (artifacts, objectives, strategies, etc.), how it is developed, that is, we have attempted to reveal which ones they are, what they are like, what they represent and how the sets of existing activities are interconnected - it means, the practices - considering leadership is contextualized, collective and relational, taking into account the group's culture, once leadership practice is shaped and legitimated by the group's culture as well as how they influence leadership. This way, researchers should understand the basic assumptions shared, the meaning of communication to the practitioners, how action is feasible, and how leaders identify the meaning of what is relevant to the followers.

\subsection{Discussion and Implications}

When we rethink leadership as cultural practice, we can point out implications to the research and leadership as practice. In relation to the research, we must readjust in its epistemological, theoretical and methodological aspects. In this way we understand that to research empirically leadership as cultural practice, the researcher should: 
a) Be engaged in the epistemology of the practice. With this proposal, we present a new view of leadership putting it close to the phenomenon, not only by exploring what leaders and followers do in the organizations, but also understanding how the organization and the coordination of activities are produced inside a collectivity - considering that the existing cultural processes guide the action and provide the basis to understand the analyzed context - subject of interest in several organizations. According to this perspective, leadership is taken as the unity of analysis, considering the practitioners (leaders and followers) as well as nonhuman elements (artifacts, aims, objectives, strategies, etc.) and taking into account how leadership is developed, that is, we try to reveal which ones they are, what they are like, what they represent and how these existing activities sets are interconnected - it means, the practices - since leadership is contextualized, collective and relational;

b) Adopt a theoretical concept of leadership as practice associated with culture. Leadership is produced as a relational process, arisen from interactions and communications among actors inside a context. Certainly, leadership is not only a result of social processes, but also a contextual element that influences the interactions. In the study of leadership as cultural practice, the researcher is concerned about how leadership practices are shaped and legitimated by the group culture, as well as the influences of such practices in the collective culture. Therefore, we must understand the shared basic assumptions, the meaning of communication to the practitioners, how the action is feasible, and how leaders identify what is relevant to the followers;

c) Follow a methodological procedure including successive movements of zooming in and zooming out from the studied leadership practices (Nicolini, 2009b) and organize interaction techniques with empirical material compatible with these procedures, such as observation, shadowing and an interview to the double (Nicolini, 2009a). The concepts of nearness and distance make part of different theories of practice and methodologies allied to practice-based studies, especially ethnography and ethnomethodology. The nearness and distance processes enable the study of practices through inside and outside analysis of the collective. Inside the collective, and so involved in the practices, the researcher can find out meanings, responsibilities and the way the practitioners act inside the collective; when he backs off he can establish connections and understand non-reflexive parts of the practices, thus enabling a better understanding about the collective 
(Bispo, 2015). In terms of ethnomethodology, as a method, the researcher's main concern should be observing and understanding how the group members act according to his point of view, leaning on the social references that he has (Garfinkel, 2006). The ethnomethodology focuses on the understanding of the experience lived by the studied group considering the production of dissemination and modification of the practices, with proximity between the researcher and the process (Francis \& Hester, 2004; Pollner \& Emerson, 2001). With the help of ethnographic approaches, it is possible to understand a human experience through the studies of events, languages, rituals, artifacts, institutions, behaviors, and interactions inside a particular community (Cunliffe, 2010). Using ethnographic approaches means living the studied culture daily, establishing a connection with the informers (Cavedon, 2014). Especially, it would be interesting to use shadowing, a technique which enables the researcher to follow, as a "shadow", a person throughout his or her daily activities, representing, this way, a manner of research that shows the mobility of contemporary life (Czarniawska, 2007). The shadowing process not only reveals the form of a person's day according to his or her performed activities, but also the subtleties of perspectives and purposes which shape such activities in the context of an organization in real time (McDonald, 2005). Through shadowing, it is possible to have a better understanding of relational complexity beyond the nucleus of leadership (Czarniawska, 2007).

Another implication of the research refers to the cross-cultural leadership field. When we consider leadership as cultural practice, the researchers of leadership of different cultures will be able to review and rethink their assumptions and guidance of research. The focus on leadership practice, organizational culture and social cultures can bring forth new views to issues such as cultural diversity inside different kinds of organizations and inside several organizational structures, the leaders' learning about conflicts and crisis including cultural diversity, and the development of a new thinking of diversity leadership.

The new view of leadership as practice has also some implications to the practices in the organizations. When managers are invited to think about their activities as leadership practice and if they think about them as leaders, they have to face a wider and practical vision of what leading means. A more accurate view about what practice leadership is, considering the importance of culture in this practice, assuredly enriches the understanding and the 
practice of the present and future managers. In this sense, leader trainers professors or coaches of all natures - can engage themselves in this new understanding of leadership and contribute to this fancy way of leadership practice. Leadership practice also encompasses international leaders who should know how to lead several cultures. The concept of leadership as cultural practice raises special attention with cross-cultural dialogue and respect to differences.

The leadership from the traditional point of view is individualized and isolated, emphasizing the leader figure, highlighting his skills. The approach to leadership as cultural practice, on the other hand, regards leadership as a collective and cultural phenomenon, representing a broad scope perspective. This way, instead of individualism, cognitivism and measurement, an approach that directs attention to the context where leadership happens, is solely constructivist, relational, collective and based on the speech, rhetoric and narrative. Thus, the meaning of practice goes along with the search for understanding of the modus operandi of leadership, allowing a direction of the studies to matters such as where the leadership work takes place, who and which nonhuman elements are involved in such work, and how it is organized, communicated and assimilated. Furthermore, the approach of leadership as cultural practice, differently from the research on leadership as practice seen until now, integrates and emphasizes the cultural dimension, since leadership is connected to a culture that comprises individual and collective beliefs, and which serves as a basis for the analysis of leadership as a collective manifestation.

Culture guides the practices of daily leadership and gives them several particular meanings. Therefore, although exogenous and endogenous practices can change the organizational culture, its own practices are incorporated and affected by wider cultural systems as well. This way, the view of leadership as cultural practice includes the explanations of actions and interactions, rebuilding the symbolic structures of knowledge and allowing leaders and followers to interpret the world according to certain forms and to behave according to the active culture.

So, the proposal of this article has the advantage of bringing forth vast knowledge about leadership from an integrated understanding point of view of the current practices, taking into account leaders, followers, context and culture. With such knowledge, the practitioners are able to better understand the work they do, as well as think over the practices considering the objectives to be achieved. On the other hand, the use of this proposal brings challenges such as how to get ample access to the environment to be 
analyzed, to follow people very closely, and to have enough time to know in details the activities performed.

\section{CONCLUSION}

Due to lack of studies about leadership as practice that take full account of the cultural dimension, this article proposes the study of leadership as cultural practice. The first step of this research was a study revision about leadership as practice. The second one was to gather these studies with the ones that treat cultural leadership and leadership as cultural practice. The third one tackles about the discussions generated by the proposal of leadership as cultural practice. The research establishes a new theoreticalconceptual path to develop research on leadership as cultural practice, based on an integrated understanding of existing practices, taking into account leaders, followers, context and culture.

Instead of focusing on the leaders' abilities and the traditional perspective on the research of leadership, the view on leadership as cultural practice focuses on the modus operandi of leadership, with a closer interaction with the practitioners. In addition, expanding the study on leadership as practice, integrating the cultural dimension, since culture is intrinsic to the phenomenon of leadership and represents an essential element on the guidance of how organizational practices are built, as well as on how leaders make decisions, act and interact.

Understanding leadership practices that occur in the organizations means to use social and cultural conditions, to answer the reasons and the way they happen. A wide understanding is essential to explain the way to organize the practices, which brings the need to know the context in which the activities occurred in every practice, the elements of the context, the manner leaders and followers negotiate and build collectivity, the practical knowledge and the historical and cultural references which measure the generated knowledge. It is also necessary to understand such process of knowledge building considering the conditions of production, maintenance and transformation.

The results of the research allow to enlarge and improve the study of leadership, considering it not only as practice, but as cultural practice. It is important to develop a referential to support the fieldwork, the analysis and the interpretation of the empirical material to the study of leadership as cultural practice. Such referential can be based on the practical references of 
the leadership areas, on the adaptation of practice-based studies of other areas of Business Management, on projects dealing with elements related to cross-culturality leadership, and on the concepts of nearness and distance (Nicolini, 2009b, 2013).

\section{REFERENCES}

Antonello, C., \& Godoy, A. (2009). Uma agenda brasileira para os estudos em aprendizagem organizacional. Revistas de Administração de Empresas, 49 (3), 266-281. doi 10.1590/S0034-75902009000300003

Bispo, M. (2013a). Aprendizagem organizacional baseada no conceito de prática: Contribuições de Silvia Gherardi. Revista de Administração Mackenzie, 14(6), 132-161. doi 10.1590/S1678-69712013000600007

Bispo, M. (2013b). Estudos Baseados em Prática: Conceitos, História e Perspectivas. Revista Interdisciplinar de Gestão Social, 2(1), 13-33.

Bispo, M. (2015). Methodological Reflections on Practice-Based Research in Organization Studies. Brazilian Administration Review, 12(3), 309-323. doi 10.1590/1807-7692bar2015150026

Bispo, M., \& Mello, A. (2012). A miopia da aprendizagem coletiva nas organizações: Existe uma lente para ela? Revista Gestão \& Planejamento, 13(3), 728-745.

Bourdieu, P. (1977). Outline of a theory of practice. Cambridge: Cambridge University Press. doi 10.1017/CBO9780511812507

Bourdieu, P. (1990). The logic of practice. Stanford: Stanford University Press.

Canato, A., Ravasi, D., \& Phillips, N. (2013). Coerced practice implementation in cases of low cultural fit: Cultural change and practice adaptation during the implementation of Six Sigma at 3M. Academy of Management Journal, 56(6), 1724-1753. doi 10.5465/amj.2011.0093

Carroll, B., Levy, L., \& Richmond, D. (2008). Leadership as practice: Challenging the competency paradigm. Journal of Strategic Contracting and Negotiation, 4(4), 363-379. doi 10.1177/1742715008095186

Cavedon, N. (2014). Método etnográfico: Da etnografia clássica às pesquisas contemporâneas. In E. Souza, Metodologias e analíticas qualitativas em pesquisa organizacional: uma abordagem teórico-conceitual. Vitória: EDUFES.

Chia, R. (2004). Strategy-as-practice: Reflections on the research agenda. European Management Review, 1, 29-34. doi 10.1057/palgrave.emr.1500012 
Chia, R., \& MacKay, B. (2007). Post-processual challenges for the emerging strategy-as-practice perspective: Discovering strategy in the logic of practice. Human Relations, 60 (1), 217-242. doi 10.1177/0018726707075291

Collinson, D., \& Collinson, M. (2009). "Blended leadership": Employee perspectives on effective leadership in the UK Further Education Sector. Leadership, 5(3), p. 365-380. doi 10.1177/1742715009337766

Cook, S., \& Brown, J. (1999). Bridging epistemologies: The generative dance between organizational knowledge and organizational knowing. Organization Science, 10(4), 381-400. doi 10.1287/orsc.10.4.381

Crevani, L., Lindgren, M., \& Packendorff, J. (2010). Leadership, not leaders: On the study of leadership as practices and interactions. Journal of Management, 26, 77-86. doi 10.1016/j.scaman.2009.12.003

Cunliffe, A. (2010). Retelling tales of the field: In search of organizational ethnography 20 years on. Organizational Research Methods, 13(2), 224-239. doi 10.1177/1094428109340041

Czarniawska, B. (2007). Shadowing and other techniques for doing fieldwork in modern societies. Malmö: Liber.

Denis, J., Langley, A., \& Sergi, V. (2012). Leadership in the plural. Academy of Management Annals, 6(1), 211-283. doi 10.1080/19416520.2012.667612

Derue, D. (2011). Adaptive leadership theory: Leading and following as a complex adaptive process. Research in Organizational Behavior, 31, 125-150. doi 10.1016/j.riob.2011.09.007

DiMaggio, P. (1997). Culture and cognition. Annual Review of Sociology, 23, 263-287. doi 10.1146/annurev.soc.23.1.263

Drath, W. (2001). The deep blue sea: Rethinking the source of leadership. San Francisco: Jossey-Bass.

Drath, W., McCauley, C., Palus, C., Velsor, E., O’Connor, P., \& McGuire, J. (2008). Direction, alignment, commitment: Toward a more integrative ontology of leadership. The Leadership Quarterly, 19, 635-653. doi 10.1016/j.leaqua. 2008.09.003

Drath, W., \& Palus, C. (1994). Making common sense: Leadership as meaningmaking in a community of practice. Greensboro: Center for Creative Leadership.

Feldman, M. (2000). Organizational routines as a source of continuous change. Organization Science, 11(6), 611-629. doi 10.1287/orsc.11.6.611. 12529

Feldman, M., \& Orlikowski, W. (2011). Theorizing practice and practicing theory. Organization Science, 22(5), 1240-1253. doi 10.1287/orsc. 1100.0612 
Ferraz, M., \& Fischer, T. (2001). Liderança e mediação da identidade: A palavra dos líderes e a voz da mídia. Revista Organizações \& Sociedade, 8(22), 1-15. doi 10.1590/S1984-92302001000300012

Fiedler, F. (1967). A theory of leadership effectiveness. New York: McGraw-Hill.

Flach, L., \& Antonello, C. (2011). Organizações culturais e a aprendizagem baseada em práticas. Cadernos EBAPE.BR, 9(1), 155-175. doi 10.1590/ S1679-39512011000100010

Fletcher, J., \& Käufer, K. (2003). Shared leadership: Paradox and possibility. In C. Pearce \& J. Conger, Shared leadership: Reframing the hows and whys of leadership. Thousand Oaks: Sage. doi 10.4135/9781452229539.n2

Francis, D., \& Hester, S. (2004). An Invitation to Ethnomethodology: Language, society and interaction. London: Sage. doi 10.4135/9781849208567

Garfinkel, H. (2006). Estudios en etnometodología. Barcelona: Anthropos.

Geiger, D. (2009). Revisiting the concept of practice: Toward an argumentative understanding of practicing. Management Learning, 40(2), 129-144. doi 10.1177/1350507608101228

Gherardi, S. (2006). Organizational Knowledge: The Texture of Workplace Learning. Oxford: Blackwell Publishing.

Gherardi, S. (2010). Telemedicine: a practice-based approach to technology. Human Relations, 63(4), 501-524. doi 10.1177/0018726709339096

Gherardi, S., Nicolini, D., \& Odella, F. (1998). Toward a social understanding of how people learn in organizations: the notion of situated curriculum. Management Learning, 29(3), 273-297. doi 10.1177/1350507698293002

Giorgi, S., Lockwood, C., \& Glynn, M. (2015). The many faces of culture: Making sense of 30 years of research on culture in organization studies. Academy of Management Annals, 9(1), 1-54. doi 10.1080/19416520.2015. 1007645

Hosking, D. (2006). Not leaders, not followers: A post-modern discourse of leadership processes. In B. Shamir, R. Pillai, M. Bligh, \& M. Uhl-Bien, Follower-centered perspectives on leadership: A tribute to the memory of James $R$. Meindl. Greenwich: Information Age Publishing.

House, R., Hanges, P., Javidan, M., Dorfman, P., \& Gupta, V. (2004). Culture, leadership, and organizations: The GLOBE study of 62 societies. Thousand Oaks: Sage. doi 10.5465/AME.2005.16965495

Howard-Grenville, J., Golden-Biddle, K., Irwin, J., \& Mao, J. (2011). Liminality as cultural process for cultural change. Organization Science, 22 (2), p. 522-539. doi 10.1287/orsc. 1100.0554 
Hui, A., Schatzki, T., \& Shove, E. (2017). The nexus of practices: Connections, constellations, practitioners. London: Routledge.

Jarzabkowski, P. (2005). Strategy as practice: An activity-based approach. London: Sage. doi 10.4135/9781446215777

McDonald, S. (2005). A qualitative shadowing method for organisational research. Qualitative Research, 5(4), 455-473. doi 10.1177/14687941050 56923

Neuman, W. (2003). Social research methods: Qualitative and quantitative approaches. Boston: Pearson Education.

Nicolini, D. (2009a). Articulating Practice through the Interview to the Double. Management Learning, 40(2), 195-212. doi 10.1177/135050 7608101230

Nicolini, D. (2009b). Zooming in and out: practices by switching theoretical lenses and trailing connections. Organizations Studies, 30(12), 1391-1418. doi 10.1177/0170840609349875

Nicolini, D. (2013). Practice theory, work, and organization: An introduction. Oxford: Oxford University Press.

Nicolini, D., Gherardi, S., \& Yanow, D. (2003). Knowing in organizations: A practice-based approach. New York: M. E. Sharpe. doi 10.4324/978131 5290973

Orlikowski, W. (2000). Using technology and constituting structures: A practice lens for studying technology in organizations. Organization Science, 11(4), 404-428. doi 10.1287/orsc.11.4.404.14600

Parry, K., \& Bryman, A. (2006). Leadership in organizations. In S. Clegg, C. Hardy, T. Lawrence, \& W. Nord, The Sage handbook of organization studies. London: Sage. doi 10.4135/9781848608030.n15

Pollner, M., \& Emerson, R. (2001). Ethnomethodology and ethnography. In P. Atkinson, A. Coffey, S. Delamont, J. Lofland, \& L. Lofland, Handbook of ethnography. London: Sage. doi 10.4135/9781848608337.n8

Raelin, J. (2011). From leadership-as-practice to leaderful practice. Leadership, 7(2), 195-211. doi 10.1177/1742715010394808

Reckwitz, A. (2002). Toward a theory of social practices: A development in cultural theorizing. European Journal of Social Theory, 5(2), 243-263. doi 10.1177/13684310222225432

Samra-Fredericks, D. (2003). Strategizing as lived experience and strategists' everyday efforts to shape strategic direction. Journal of Management Studies, 40(1), 141-174. doi 10.1111/1467-6486.t01-1-00007 
Sandberg, J., \& Dall'Alba, G. (2009). Returning to practice new: A life-world perspective. Organization Studies, 30(12), 1349-1368. doi 10.1177/017084 0609349872

Santos, L., \& Silveira, R. (2015). Por uma epistemologia das práticas organizacionais: a contribuição de Theodore Schatzki. Revista Organizações E Sociedade, 22 (72), 79-98. doi 10.1590/1984-9230724

Schatzki, T. (2001). Introduction: practice theory. In T. Schatzki, K. Knorr Cetina, \& E. von Savigny, The practice turn in contemporary theory. New York: Routledge.

Schatzki, T. (2006). On organizations as they happen. Organization Studies, 27(12), 1863-1873. doi 10.1177/0170840606071942

Schein, E. (1992). Organizational culture and leadership. San Francisco: JosseyBass.

Silva, E., \& Gonçalves, C. (2016). Practice genealogy and its implications for strategy as practice. Revista de Administração Mackenzie, 17(4), 130-152. doi 10.1590/1678-69712016/administracao.v17n4p130-152

Smircich, L., \& Morgan, G. (1982). Leadership: The management of meaning. The Journal of Applied Behavioral Science, 18(3), 257-273. doi 10.1177/0021 88638201800303

Smith, P., \& Peterson, M. (1989). Leadership, organizations and culture. London: Sage.

Stogdill, R. (1948). Personal factors associated with leadership: A survey of the literature. Journal of Psychology, 25, 35-71. doi 10.1080/00223980. 1948.9917362

Stogdill, R., \& Coons, A. (1957). Leader behavior: Its description and measurement. Columbus: Bureau of Business Research, Ohio State University.

Swidler, A. (2001). What anchors cultural practices. In T. Schatzki, K. Knorr Cetina, \& E. von Savigny, The practice turn in contemporary theory. New York: Routledge.

Uhl-Bien, M. (2006). Relational leadership theory: Exploring the social processes of leadership and organizing. The Leadership Quarterly, 17, 654-676. doi 10.1016/j.leaqua.2006.10.007

Vaara, E., \& Whittington, R. (2012). Strategy-as-Practice: Taking Social Practices Seriously. Academy of Management Annals, 6(1), 285-336. doi 10.1080/1941 6520.2012 .672039

Van Maanen, J. (1979). The fact of fiction in organizational ethnography. Administrative Science Quarterly, 24(4), 539-550. doi 10.2307/2392360 
Varney, J. (2009). Leadership as meaning-making. Human Resource Management International Digest, 17(5), 3-5. doi 10.1108/09670730910974251

Vine, B., Holmes, J., Marra, M., Pfeifer, D., \& Jackson, B. (2008). Exploring co-leadership talk through interactional sociolinguistics. Leadership, 4(3), 339-360. doi 10.1177/1742715008092389

Whittington, R. (2003). The work of strategizing and organizing: For a practice perspective. Strategic Organization, 1(1), 117-125. doi 10.1177/147 612700311006

Whittington, R. (2006). Learning more from failure: Practice and process. Organization Studies, 27(12), 1903-1906. doi 10.1177/0170840606071945

Wood, M. (2005). The fallacy of misplaced leadership. Journal of Management Studies, 42(6), 1101-1121. doi 10.1111/j.1467-6486.2005.00535.x

\title{
ABOUT THE AUTHORS
}

\author{
OTACÍLIO TORRES VILAS-BOAS \\ $\mathrm{PhD}$ in Management, \\ Universidade Federal da Bahia. \\ Analyst in Tribunal Regional do Trabalho da $2^{\text {a }}$ Região. \\ Av. Reitor Miguel Calmon, s/n, Vale do Canela - Salvador - Bahia - Brazil - CEP 40110-903 \\ E-mail: otaciliotorres@hotmail.com \\ ORCID: 0000-0002-6438-7748 \\ EDUARDO PAES BARRETO DAVEL \\ $\mathrm{PhD}$ in Management, \\ HEC Montreal. \\ Professor for the Management College, \\ Universidade Federal da Bahia. \\ Av. Reitor Miguel Calmon, s/n, Vale do Canela - Salvador - Bahia - Brazil - CEP 40110-903 \\ E-mail: davel.eduardo@gmail.com \\ ORCID: 0000-0003-0610-6474 \\ MARCELO DE SOUZA BISPO \\ $\mathrm{PhD}$ in Management, \\ Universidade Presbiteriana Mackenzie. \\ Associate professor at the Department of Management, \\ Universidade Federal da Paraíba. \\ UFPA Campus I - CCSA, Cid. Universitária - João Pessoa - Paraíba - Brazil - CEP 58051-900 \\ E-mail: marcelodesouzabispo@gmail.com \\ ORCID: 0000-0002-5817-8907
}


Leadership as cultural practice

\section{EDITORIAL BOARD}

Editor-in-chief

Silvio Popadiuk

Associated Editor

Dimária Silva e Meirelles

Technical Support

Patricia Betencourt

Vitória Batista Santos Silva

\section{EDITORIAL PRODUCTION}

Publishing Coordination

Irina Migliari

Language Editor

Caio Rubens Salles

Editorial Trainee

Maria Luiza Vanz

Layout Designer

Emap

Copyeditor

Irina Migliari
Graphic Designer

Libro 